\title{
4. The Ideological Contest
}

\section{Carol Johnson}

The year before Kevin Rudd won office, Julia Gillard (2006, 106-7) discussed how to defeat the Howard Government. She argued that Labor needed to 'unshackle' itself from the factional system. Ideological differences between the factions were no longer important given that members of Labor's left factions were often amongst the keenest supporters of market-oriented policies. She also argued that moving to the left to oppose Howard's so-called Culture Wars would not work. Rather, one needed to combat Howard by building 'a broader vision of Australia which is inclusive of those who rightly worry about jobs, health, education, roads, border security and the like' (Gillard 2003, 107).

Gillard's comments are instructive. First, they explain how Gillard, as a member of a left faction, gained the support of right factional leaders to topple Rudd. Second, despite her avowedly 'post-ideological' position, they explain some of her own ideological influences in the 2010 campaign, including why the ideological differentiation with the Liberals was not as explicit as it could have been on economic issues such as market failure. Third, her arguments about the need to address mainstream voters' concerns (as she conceived them) help to explain why Labor had such a small-target strategy on social issues and the steps taken to reassure socially conservative voters on issues from asylum-seekers to immigration. In other words, Gillard's views influenced the 2010 campaign; key features cannot be explained just in terms of the influence of Labor figures such as Mark Arbib and Karl Bitar.

On the eve of his removal as leader, Rudd (2010) suggested that supporting Gillard would involve a move to the right on issues such as asylum-seekers and climate change. Rudd had a point and it was not just because Gillard was electorally pragmatic or trying to downplay her left credentials in order to get right-wing support. Gillard's position on climate change and asylum-seekers will be discussed later. Her views on markets, however, also suggest a degree of difference with Rudd. For Rudd was not the only ghost of leaders past who haunted Gillard. The other was Mark Latham - a campaign distraction in 2007, but also a leader to whom Gillard had once been close. When reflecting on Labor's 2004 election defeat, Gillard had argued that Labor should ditch any old ideological allegiances to the public as opposed to the private sector:

People rightly expect a government that will strive to meet [their] expectations, free of the ideological public/private divides...We have not yet extended that same flexibility (as in past economic reforms) - and 
in some cases market forces - to expanding the opportunity, delivering more effective public services and protecting our environment. (Cited in Schubert 2004)

Gillard went on to praise Latham's performance as Labor leader-and her comments reflect his influence. Latham (2003a; see further Johnson 2004) saw markets as a cleansing force that would utilise market competition to undermine the position of overly powerful elite capitalists. His arguments help to explain the appeal of neo-liberalism to some social democrats (Johnson 2007, 180). Latham, however, went further than most social democrats, including Gillard, by arguing that the struggle between labour and capital had now been replaced with aspirational voters and an information economy (Johnson 2004, 537). Significantly, as we will see later in terms of Gillard's 2010 position, Latham (2003b) had also argued for a focus on hard work and responsibility, and for downplaying 'symbolic' social issues, to win key suburban seats.

Rudd also frequently supported markets but identified major areas of market failure. Indeed, recognition of market failure underlay Rudd's arguments in the 2007 election campaign for the need for government to regulate fair working conditions (as opposed to the market commodification of people he believed underlay WorkChoices); the need for major government expenditure and involvement to provide high-speed broadband; and the need to tackle climate change, including putting a price on carbon (see Rudd 2006a, 2006b, 2007). These deep reservations about markets subsequently reinforced Rudd's (2009) support for a substantial stimulus package during the global financial crisis (GFC).

In contrast, Gillard (2010c) only occasionally criticised the market, although she noted the need to engage in 'market design' to 'unblock' market failures. Yet her comments on 'market design' said much less about market failure than some of the writings by the Per Capita Think Tank that had influenced her use of that term (Hetherington 2010). Consequently, there was no overarching narrative into which to fit Gillard's support for measures such as a carbon price. The market failures of the GFC were not outlined during the election campaign but alluded to only indirectly through her argument that the Government's stimulus package had supported jobs. There was no detailed attempt to explain a Keynesian argument that government deficits were necessary and justifiable in times of cyclical capitalist downturn to keep up employment and consumption. While Rudd's critiques of the downside of free-market capitalism were prominent, one was left with little idea of what Gillard (2010c) thought had caused the GFC.

Indeed, the Gillard Government's (and the public's) focus on returning the budget to surplus so quickly and tackling government debt (despite the low level of net public-sector debt as a proportion of GDP compared with other Organisation 
for Economic Cooperation and Development countries such as Britain) reflected an ongoing neo-liberal influence that had also been present under Rudd (but had been partially balanced by his critique of extreme neo-liberalism). Gillard's education revolution also reflected Latham's neo-liberal influences, including implementing market competitiveness via parental choice in the MySchool web site and an emphasis on individual capability (Gillard 2010b).

Gillard did claim to be still committed to a carbon price but her electoral cautiousness, and desire to get the budget back into surplus quickly, had apparently led her and Wayne Swan to argue initially that an emissions trading scheme (ETS) should be dumped - a move reportedly fiercely resisted by Climate Change Minister Penny Wong and Finance Minister Lindsay Tanner (Franklin 2010b, 4; Taylor 2010). The end result was an argument for the longterm delay of an ETS until 'consensus' had been achieved (Oakes 2010), partly via the utilisation of a (much derided) citizens' assembly. Labor's support for the Mining Super Profits Tax (that sparked a major campaign against it by the miners before Gillard's concessions bought off some of the biggest opponents) was also based not only on addressing the issues of a two-speed economy but also on finding a revenue source for infrastructural and other expenses that would avoid a further blowout of the bottom line.

Gillard did make some key distinctions between Labor and the Liberals. For example, she claimed that she had felt obliged to become leader because 'I love this country and I was not going to sit idly by and watch an incoming Opposition cut education, cut health and smash rights at work' (Gillard and Swan 2010). Nonetheless, the lack of a more explicit, broader ideological differentiation between Liberal and Labor might have contributed to the high rate of informal votes and was exacerbated by Labor's small-target strategy on social issues.

The scare campaign against Abbott was largely targeted at the alleged risk he posed on issues of economic management and industrial relations. He was not targeted for his views on social issues such as gender-including his claims during the campaign that Aussie blokes had trouble dealing with contemporary society because 'hard wired into just about every bloke is this kind of hunter warrior instinct' (cited in Kearney 2010). Worried about neutralising the effect of her unmarried, childless, atheist persona, Gillard acknowledged the importance of Australia's 'Christian heritage' for opposing same-sex marriage (cited in Shanahan and Kelly 2010), thereby continuing the previous Labor strategy of using same-sex marriage as a 'sign' of social conservatism.

On asylum-seeker issues, Gillard (ABC 2010a) aimed to steer a middle path between right and left, claiming that one should demonise neither as 'rednecks' people who were understandably anxious about boats arriving nor as 'bleeding hearts' those concerned about children behind razor wire, but feel empathy for both. 
Consequently, Gillard (Oakes 2010) displayed little empathy for adult asylumseekers, although showing motherly concern for their 'innocent' children. She did use figures on the low numbers of asylum-seekers to try to undermine Abbott's scare campaign (O'Brien 2010a). Nonetheless, her comments about a 'sustainable' rather than a 'big' Australia (Franklin 2010a) were commonly seen as a dog whistle on immigration issues as well as an attempt to address legitimate concerns about outer-urban infrastructure and transport issues. On both asylum and immigration issues, Gillard was trying to address the tensions that she had previously argued Howard and Abbott had exploited between Labor's 'blue collar' and 'tertiary educated' constituencies (Gillard 2003, 104). This framing of Labor's electoral problems risks reinforcing socially conservative constructions both of working-class attitudes and of working-class identity. It downplays the ethnic and social diversity within the Australian working class itself as well as potential links between the working class and other disadvantaged groups. It also reveals the ongoing influence on the Labor Party of Howard's neo-liberal constructions of so-called 'elite', politically correct issues and 'mainstream' issues (Johnson 2007, 39-50).

The result was an even less explicit differentiation on social issues than had occurred during the 2007 Rudd campaign. Admittedly, Gillard's gender was meant to be a sign of progressive social views, just as Rudd's multi-racial family and Mandarin-speaking abilities had been used to project this symbolically in 2007. Yet few of the differences between Gillard and Abbott on social issues were highlighted during the campaign, perhaps out of a belief that they would alienate the outer-suburban voters, such as those of western Sydney, to whom the campaign appeared to be held hostage (Jones 2010). Labor's paid parental-leave scheme was an important innovation for parents, although Abbott's scheme was arguably more financially generous, particularly to middle and higher income earners. Labor's announcement of support for an extra two weeks' support for fathers when the child was born also encouraged men to play more of a parenting role (ALP 2010). Gillard (2010a) claimed that the reason Labor reneged on its 2007 promises to massively extend day care and childcare centre provision was because of the collapse of the ABC Learning childcare centres.

Gillard's emphasis on work had more in common with a Blairite conception focusing on work as the key to social inclusion and less in common with the broader Keatingite conception of social inclusion that included social movement, Indigenous and multicultural issues (Johnson and Tonkiss 2002). Lowitja O'Donoghue complained during Gillard's $Q \& A$ appearance about the lack of content on Indigenous issues during the election campaign (ABC 2010a). Though Gillard's proposals for modernising welfare by increasing responsibility harked back to a Keatingite agenda of reciprocal obligation, measures such as 
partial income quarantining for those failing to act responsibly went much further than Keating's policies (Gillard and ALP 2010). The emphasis on hard work and responsibility to attract suburban voters also had echoes of Latham.

Overall, there was little new in Labor's strategy; it harked back to earlier arguments about information technology and the education revolution that had been used by Kim Beazley and Latham as well as by Rudd in 2007. It was, however, 'Rudd-lite' in its arguments about the need for a national broadband network and a carbon price but without the related emphasis on market failure driving the need for state action. It was arguably an even smaller-target campaign on progressive social issues than in Labor campaigns under Howard. Like previous small-target campaigns, it arguably reinforced, rather than undermined, the socially conservative views advocated by the Liberals. It also apparently drove many disillusioned former Labor voters to vote for the Greens - a result that saw a major reduction in Labor's primary vote with longer-term implications for ideological challenges from the left that Labor still has to come to grips with.

Significantly, Adam Bandt, the new Greens MP for Melbourne, ran not only on the basis of supporting a carbon tax and same-sex marriage and abolishing mandatory detention of asylum-seekers but also on a policy of abolishing Howard's draconian Australian Building and Construction Commissionretained by the Gillard Government. His reputation as an industrial lawyer was partly based on a successful appeal to the International Labour Organisation (ILO) against aspects of Labor's Fair Work Act. Meanwhile, former NSW Labor Premier Morris Iemma pointed out that the anti-immigration message of a sustainable Australia not a big Australia had led to a massive drop in the multicultural vote in Sydney electorates (ABC 2010b).

There were substantial swings against Labor in parts of the electorate of Minister for Sustainable Development Tony Burke which had a high migrant population (Saulwick 2010). Such developments problematise Labor's understandings of how 'progressive' social issues work out amongst working-class and suburban electorates - including overly simplistic conceptions of tensions between suburban 'blue collar' and inner-city 'tertiary educated' voters. Here, as elsewhere, Gillard's original arguments regarding how to defeat Howard fed into her views about how to defeat Abbott (whom she had identified as one of Howard's key henchmen).

\section{Abbott}

Despite Labor's small-target strategy, there were still underlying ideological differences between Labor and Liberal, even if they were not always highlighted in the election campaign. The differences on economic policy were apparent well 
before the election in a piece Abbott wrote in response to Rudd's (2009) article on the GFC in The Monthly. Abbott (2009) lauded the role of market forces, arguing that 'greater exposure to market forces over the last three decades has eventually led to more jobs, higher pay and much greater wealth'. He argued against Rudd's analysis of market failure as a cause of the GFC, claiming that Rudd 'has confused a cyclical (if severe) downturn with a fundamental crisis of capitalism' (Abbott 2009).

Consequently, Rudd's essay was 'a rallying cry for everyone who doesn't trust markets and who thinks that the government is far more likely to spend money wisely than misguided individuals' (Abbott 2009). Abbott (2009) argued that Rudd's second, $\$ 42$ billion stimulus package was unnecessary - a sign of panic and a justification for shifting 'from being an "economic conservative" to a born-again socialist'. Furthermore, Abbott (2009) claimed that neo-liberalism had 'never really existed outside the theorising of the academic Right and the fantasising of the academic Left'. Abbott's emphasis on reducing government debt showed, however, clear neo-liberal influences, as did his arguments that markets, and the individuals involved, make better financial and investment decisions than governments.

Nonetheless, the Liberals had learned their electoral lesson about introducing extreme market policies in the workplace. Abbott (Mitchell 2010) claimed that WorkChoices was 'dead, buried and cremated'. He still managed, however, to mobilise anti-union arguments by suggesting that prominent unionists were amongst the 'faceless men' who had deposed Kevin Rudd (Curtis 2010). I have argued elsewhere that WorkChoices reinvigorated a class-based theory of exploitation in the 2007 campaign as opposed to the normal neo-liberal arguments that 'mainstream' taxpayers were being ripped off by government largesse given to politically correct elites and special interests (Johnson 2010). Abbott's proclaimed ditching of WorkChoices attempted to head off a Labor and union mobilisation of class issues. In addition, Abbott's arguments about 'all talk and no action' evoked a conception that opposed the Labor chattering classes with ordinary practical people who got the important things done.

The repeated images of Abbott in protective vests, driving forklifts or engaging in other 'action man' activities, reinforced that conception. Abbott's (2010a) critique of government waste suggested that taxpayers' dollars were now being ripped off, not so much because of 'special interests' as because of an incompetent, spendthrift government. He also suggested that the Government would be imposing big new taxes to further its environmental agenda, and that, at the least, climate change issues were exaggerated and could be dealt with by the Liberals' 'direct action' measures (Abbott 2010a). In the process, Abbott was mobilising a particular version of masculinity tied to a version of neo-liberalism. 
At the same time, Abbott tried to tackle his problems in appealing to women voters by championing a generous parental-leave scheme funded from a levy on big business - a move that some commentators thought owed more to the past ideological influence of B. A. Santamaria on his thought than neo-liberalism (Kelly 2010). Abbott argued that it was 'not just a visionary social reform but it is an important economic reform too. It will...give women the real choice that they need and have been denied for too long' (Gillard and Abbott 2010). He also appeared regularly in public with his wife and/or daughters.

Abbott proposed a number of measures designed to increase employment participation - from an incentive to employers to take on seniors, relocation allowances and job commitment bonuses for long-term unemployed young people to training packages for job seekers. He acknowledged the influence of Noel Pearson on his thought on employment capability issues (Abbott 2010b). Abbott's (and Pearson's) arguments reflected a neo-liberal, individual capability approach (Jayasuriya 2006, 34-53, 161-2).

My ambition is for us to make the journey from welfare state to opportunity society. An opportunity society which preserves the comprehensive safety net but which eliminates the cancer of passive welfare which has caused intergenerational welfare to become a tragic way of life for too many of our fellow Australians. (Abbott 2010b)

Abbott's key ideas were summed up clearly and succinctly in the Liberals' 'Action Contract: A strong plan for Australia'. Key elements of this plan included rejecting 'Labor's massive new mining tax and other taxes that hurt productivity', restoring budget surpluses and repaying Labor's debt, ending government waste, protecting the private health system while also improving the public one, border security and restoring work for the dole (Liberal Party of Australia 2010). Labor had been 'wasting billions on pink batts and overpriced school halls. They're borrowing \$100 million every single day, and they're threatening our economic future with their great big new tax on mining' (Gillard and Abbott 2010).

Abbott's agenda was not a new one. He was in fact running on a very traditional Liberal agenda, revisiting strategies and familiar arguments used in past election campaigns. His border-security arguments drew heavily on arguments from the 2001 election campaign. His focus on economic management drew on arguments that John Howard had continually made that the Coalition was a better economic manager and that Labor was economically 'risky'. The difference was that Abbott was now focused on the Rudd and Gillard Governments' stimulus debt, new taxes and claims of waste, rather than focusing on Hawke and Keating Government issues of spending and interest rates. 


\section{The Election Aftermath}

As discussed in depth elsewhere in this book, neither Labor nor the Coalition won the 2010 election directly. It is worth noting, however, that Abbott's problems gaining the support of the rural independents were partly a legacy of the neo-liberal ideology of the Howard years and the extent to which The Nationals had been pulled in to support their Coalition partner's free-market agenda, with its smaller role for government. Rob Oakeshott claimed to be 'more Liberal-leaning' on economic policy (cited in Silmalis 2010) than he was on social policy but still saw the importance of substantial government funding for broadband and hospitals as important (Oakeshott 2010). Tony Windsor (2010) also nominated government service provision - in the form of health care and broadband - as major issues for his constituents. Windsor (2010) justified his position to his conservative constituents by arguing that '[p]hilosophy, in terms of both these parties, died about a decade ago or probably longer'. He still said, however, that 'possibly the most critical' factor in his decision was broadband (Windsor 2010).

The Government's major role in providing broadband did display a different philosophical position from the Liberals (Johnson 2011). After all, Abbott (O'Brien 2010b) opposed Labor's broadband scheme by arguing that 'we just don't believe that re-creating a government-owned telecommunications monopoly is the way to go. We think that competition and diversity of technology is the way to go.' Despite his eventual support for the Coalition forming government, Bob Katter was even scathing of the impact on his constituents of the Coalition's deregulation (of milk), free-trade agreements (on sugar) and privatisation (of Telstra) (O'Brien 2010c).

\section{Conclusion}

The election outcome was influenced by multiple factors, including a Labor government that had failed to manage policy implementation or to communicate effectively, and a leadership coup. There was also the much criticised influence of NSW Labor powerbrokers on the campaign - although this chapter has identified some of the earlier antecedents in Labor strategy. Both parties now find themselves facing long-term ideological dilemmas. Under Rudd, Labor had been forging a relatively clear ideological narrative, involving critiques of neoliberalism and market failure (even if it was increasingly poorly communicated by Rudd himself). According to that narrative, the inhumanity of extreme freemarket policies, typified by WorkChoices, combined with the market failures typified by climate change, the GFC and the poor provision of infrastructure, 
such as broadband, demonstrated the failures of neo-liberal ideology. A socialdemocratic approach, based on a judicious use of market forces combined with government regulation, infrastructure spending and provision of services, was therefore necessary.

That narrative was not so clearly articulated by Julia Gillard. This is despite the fact that, while Gillard might be less critical of markets and neo-liberalism than Rudd was, she still has clear ideological differences with Abbott when it comes to the role of government in the economy and society, as her comments on issues ranging from health and education to broadband and industrial relations reveal. Labor is, however, now under challenge from more radical Greens perspectives, and Labor's small-target strategy and dog whistling on issues such as immigration saw very little said about broader conceptions of social inclusion. Gillard (2007) had celebrated the 'rebirth' of Labor's interest in ideas several years before, arguing that ' $[w]$ e must have the capacity to mould the wider political and intellectual agenda if we want to achieve government, hold on to it, and use it to change the country for the better'. The result of the 2010 election suggests that Labor still has a lot of intellectual work to do.

The Liberals are not, however, without their ideological dilemmas, too. The labour-market reform that Howard, Costello and Abbott himself had once seen as being crucial to their ideological agenda proved so electorally unpopular that Abbott had to declare its political cremation (although the Coalition might have tinkered with the existing regulations if elected). Meanwhile, free-market policies and problems of market failure (for example, in regard to broadband) increased support for independents in country and regional areas and contributed to the Coalition's failure to form government. In short, the 2010 election campaign demonstrated that both parties face ongoing ideological dilemmas.

\section{References}

Abbott, Tony. 2009. 'Misguided, would-be Messiah'. The Weekend Australian, 7 February, viewed 13 December 2010, <http://www.tonyabbott.com.au/ LatestNews/ArticleswrittenbyTony/tabid/87/articleType/ArticleView/ articleId/7045/MISGUIDED-WOULD-BE-MESSIAH.aspx>

Abbott, Tony. 2010a. Address to the Liberal Party, 151st Victorian Division, State Council, 17 April, Melbourne, viewed 15 July 2010, <http://www. tonyabbott.com.au/LatestNews/Speeches/tabid/88/articleType/ArticleView/ articleId/7342/Address-to-the-Liberal-Party-151st-Victorian-Division-StateCouncil-Melbourne-17-04.aspx> 
Abbott, Tony. 2010b. National Press Club address, 17 August, Canberra, viewed 3 September 2010, <http://www.tonyabbott.com.au/LatestNews/Speeches/ tabid/88/articleType/ArticleView/articleId/7632/National-Press-ClubAddress-Canberra.aspx $>$

Australian Broadcasting Corporation (ABC). 2010a. 'Julia Gillard joins $Q \& A$ '. Q\&A, 9 August, ABC TV, viewed 28 August 2010, <http://www.abc.net.au/ tv/qanda/txt/s2971154.htm?show=transcript $>$

Australian Broadcasting Corporation (ABC). 2010b. "NSW disease" blamed for Labor loss'. Stateline New South Wales, 27 August 2010, ABC TV, viewed 6 September 2010, <http://www.abc.net.au/news/video/2010/08/27/2995969. htm? site= perth $>$

Australian Labor Party (ALP). 2010. Paid paternity leave, Australian Labor Party, Canberra, viewed 2 September 2010, <http://www.alp.org.au/agenda/ more---policies/paid-paternity-leave/>

Curtis, Lyndal. 2010. 'Interview with Tony Abbott'. AM, 25 June, ABC Radio, viewed 3 September 2010, <http:/tonyabbott.com.au/LatestNews/ PressReleases/tabid/86/ArticleType/ArticleView/ArticleID/7486/Default. $\operatorname{aspx}>$

Franklin, Matthew. 2010a. 'Not going forward PM'. The Australian, 21 July, $1-2$.

Franklin, Matthew. 2010b. 'Mistakes, we made a few: Rudd shares the blame for Labor's errors'. The Australian, 24 November, 1, 4.

Gillard, Julia. 2003. 'Winning the culture war'. The Sydney Papers (Summer): 98-107.

Gillard, Julia. 2006. 'Courage, convictions \& the community, the next ten years'. The Sydney Papers (Autumn): 102-10.

Gillard, Julia. 2007. Fabian Society Annual Dinner speech, 31 August, viewed 5 September 2007, <http://www.alp.org.au/media/0807/spedlop310.php>

Gillard, Julia. 2010a. Radio Interview, ABC 774 [Melbourne], 27 April, ABC Radio, viewed 31 August 2010, <http://www.australia.to/2010/index. php?option $=$ com_content $\&$ view $=$ article $\& i d=2413$ :julia-gillard-radiointerview-on-abc-774-melbourne-\&catid=100:just-in \&Itemid=176>

Gillard, Julia. 2010b. Australia's productivity challenge: a key role for education, Speech to John Curtin Institute of Public Policy, 10 June, Minister's Media 
Centre, Department of Education, Employment and Workplace Relations, Canberra, viewed 31 August 2010, <http://www.deewr.gov.au/Ministers/ Gillard/Media/Speeches/Pages/Article_100610_130719.aspx>

Gillard, Julia. 2010c. Moving forward to a stronger and fairer economy, Speech to the National Press Club, 15 July, Canberra, viewed 6 July 2010, <http:// www.pm.gov.au/node/6892>

Gillard, Julia. 2010d. Interview transcript, Radio 2UE [Sydney], 21 July, viewed 21 July 2010, <http://www.alp.org.au/federal-government/news/transcript-2ue-interview/>

Gillard, Julia and Abbott, Tony. 2010. 'Leaders debate', National Press Club, 25 July, Canberra, viewed 3 September 2010, <http://www.tonyabbott.com. $\mathrm{au} /$ LatestNews/InterviewTranscripts/tabid/85/articleType/ArticleView/ articleId/7510/Leaders-Debate-National-Press-Club.aspx $>$

Gillard, Julia and Australian Labor Party (ALP). 2010. Modernising Australia's welfare system, Labor Party Policies, Australian Labor Party, Canberra, viewed 27 August 2010, <http://www.alp.org.au/agenda/more---policies/ modernising-welfare/>

Gillard, Julia and Swan, Wayne. 2010. Press conference with the Hon. Wayne Swan MP, Deputy Prime Minister, 24 June, Parliament House, Canberra, viewed 26 June 2010, <http://www.deewr.gov.au/Ministers/Gillard/Media/ Transcripts/Pages/Article_100624_152904.aspx>

Hetherington, David. 2010. 'A fairer design for markets'. Per Capita, viewed 31 August 2010, <http://www.percapita.org.au/01_cms/details.asp?ID=243>

Jayasuriya, Kanishka. 2006. Statecraft, Welfare, and the Politics of Inclusion. Basingstoke, UK: Palgrave Macmillan.

Johnson, Carol. 2004. 'Mark Latham and the ideology of the ALP'. Australian Journal of Political Science 39: 535-52.

Johnson, Carol. 2007. Governing Change: From Keating to Howard [Second edition]. Perth: API Network.

Johnson, Carol. 2010. 'The ideological contest'. Australian Cultural History 28(1): 7-14.

Johnson, Carol. 2011. 'The politics of broadband: Labor and new information technology from Hawke to Gillard'. Australian Journal of Political Science.

Johnson, Carol and Tonkiss, Fran. 2002. 'The third influence: the Blair Government and Australian Labor'. Policy and Politics 30(1): 5-18. 
Jones, Tony. 2010. 'Labor campaign panned by pioneer pollster', [Interview with Rod Cameron], Lateline, 8 September, ABC TV, viewed 10 September 2010, <http://www.abc.net.au/lateline/content/2010/s3006629.htm>

Kearney, Simon. 2010. 'Blokes are doing it tough: Abbott'. Sunday Mail, 15 August, 11.

Kelly, Paul. 2010. 'Abbott plays a decisive card'. The Australian, 13 March, viewed 3 September 2010, <http://www.theaustralian.com.au/news/ opinion/abbott-plays-a-decisive-card/story-e6frg6zo-1225840206167>

Latham, Mark. 2003a. Competitive capitalism versus crony capitalism: the difference between Labor and Liberal, Speech to the International Chief Executive Officers Forum, 19 August, Canberra, viewed 19 September 2005, <http://www.smh.com.au/articles/2003/08/19/1061261153599.html>

Latham, Mark. 2003b. From the Suburbs: Building a nation from our neighbourhoods. Annandale, NSW: Pluto Press.

Liberal Party of Australia. 2010. The Liberals Our Action Contract: A strong plan for Australia, Liberal Party Policies, Liberal Party of Australia, Barton, ACT, viewed 8 September 2010, <http://www.liberal.org.au/ /media/Files/ Policies\%20and\%20Media/Our\%20Action\%20Contract.ashx>

Mitchell, Neil. 2010. 'Interview with Tony Abbott', Radio 3AW [Melbourne], 19 July, viewed 3 September 2010, <http://www.tonyabbott.com.au/ LatestNews/InterviewTranscripts/tabid/85/ArticleType/ArticleView/ ArticleID/7496/Default.aspx>

Oakes, Laurie. 2010. 'Interview with Julia Gillard'. Today, 27 June 2010, Channel Nine, viewed 29 June 2010, <http://today.ninemsn.com.au/article. aspx?id=1076748>

Oakeshott, Rob. 2010. 'Transcript of announcement'. The Age, 7 September, viewed 7 September 2010, <http://www.theage.com.au/federal-election/ transcript-of-rob-oakeshotts-announcement-20100907-14zex.html>

O'Brien, Kerry. 2010a. 'Gillard's first day in office'. 7.30 Report, 24 June, ABC TV, viewed 26 June 2010, <http://www.abc.net.au/7.30/content/2010/ s2936464.htm>

O'Brien, Kerry. 2010b. 'Abbott quizzed on broadband and economy', [Interview with Tony Abbott]. 7.30 Report, 10 August, ABC TV, viewed 31 August 2010, <http://www.abc.net.au/7.30/content/2010/s2979381.htm> 
O'Brien, Kerry. 2010c. 'Independents: preparing for the pitches', [Interview with Tony Windsor, Rob Oakeshott and Bob Katter],.7.30 Report, 22 August, ABC TV, viewed 3 September 2010, <http://www.abc.net.au/7.30/content/2010/ s2990184.htm>

Rudd, Kevin. 2006a. 'Child of Hayek'. The Australian, 20 December, 12.

Rudd, Kevin. 2006b. 'Howard's brutopia: the battle of ideas in Australian politics'. The Monthly, November, 46-50.

Rudd, Kevin. 2007. Radio interview, ABC Melbourne, 11 April, viewed 24 April 2007, <http://www.alp.org.au/media/0407/inlool11.php>

Rudd, Kevin. 2009. 'The global financial crisis'. The Monthly, February, 20-29.

Rudd, Kevin. 2010. Transcript of press conference with the Prime Minister, 23 June, Parliament House, Canberra, viewed 24 August 2010, < http://pmrudd. archive.dpmc.gov.au/node/6848>

Saulwick, Jacob. 2010. 'Upset migrants turn on ALP'. Sydney Morning Herald, 24 August, 6.

Schubert, Mischa. 2004. 'Labor must embrace market: Gillard'. The Age, 14 December, 4 .

Shanahan, Dennis and Kelly, Paul. 2010. 'I'll do it my way, declares Julia Gillard'. The Australian, 20 August, viewed 4 September 2010, <http:// www.theaustralian.com.au/national-affairs/ill-do-it-my-way-declares-juliagillard/story-fn59niix-1225907498894>

Silmalis, Linda. 2010. 'Abbott warned: rein in your MPs'. The Sunday Telegraph, 29 August, viewed 3 September 2010, <http://www.news.com.au/features/ federal-election/rein-in-your-mps-rob-oakeshott-warns-tony-abbott/storyfn5tas5k-1225911345298>

Taylor, Lenore. 2010. 'Decision that shattered faith in $\mathrm{PM}^{\prime}$. Sydney Morning Herald, 5 June, viewed 10 July 2010, <http://www.smh.com.au/opinion/ politics/decision-that-shattered-faith-in-pm-20100604-xkiu.html $>$

Windsor, Tony. 2010. 'Transcript of announcement'. The Age, 7 September, viewed 7 September 2010, <http://www.theage.com.au/federal-election/ transcript-of-tony-windsors-announcement-20100907-14zew.html?utm_ source $=$ twitterfeed \&utm_medium $=$ twitter $>$ 